\title{
Optimizing the Cutting Time and Surface Finish for EDM- Wire Cut Process of AISI 1045 Steel
}

\author{
Rusdi Nur ${ }^{1, \mathrm{a}}$, Muas M. ${ }^{1, \mathrm{~b}}$ and Syah Risal ${ }^{2, \mathrm{c}}$ \\ ${ }^{1}$ Mechanical Engineering Department, Politeknik Negeri Ujung Pandang, Jalan Perintis Kemerdekaan Km. 10 Makassar, \\ South Sulawesi, 90245, Indonesia \\ ${ }^{2}$ Teknika Study Program, Politeknik Ilmu Pelayaran, Jalan Tentara Pelajar No. 173 Makassar, South Sulawesi, 90165 , \\ Indonesia \\ a rusdinur@poliupg.ac.id, \\ ${ }^{\mathrm{b}}$ muas@poliupg.ac.id \\ c syahrisalsalzafran@yahoo.com
}

\begin{abstract}
This paper aims to optimize the machined surface as well as to study the effect of current strength and wire speed on wire cut machining on AISI 1045 steel against the timing of roughness of straight gear surface. The surface results analyzed are the surface roughness values obtained by conducting surface roughness testing. Variations of current used are 3 amperes, 5 amperes, and 7 amperes, while the wire speed used is $8 \mathrm{~mm} / \mathrm{min}, 10 \mathrm{~mm}$, $\mathrm{min}$, and $12 \mathrm{~mm} / \mathrm{min}$. In the process of wire cut machining is used a brass cutting material with $0.25 \mathrm{~mm}$ wire diameter. The results showed that the greater the current and wire speed used then the surface roughness value will be lower, otherwise the smaller current and wire speed used then the surface roughness value will be higher. The results of data analysis using ANOVA analysis, correlation, and regression method obtained optimal condition to get low surface roughness value and fast cut time that is at 7 amperes current with wire speed $8 \mathrm{~mm} / \mathrm{min}$.
\end{abstract} steel.

Keywords-Wire cut; surface finish; cutting time; AISI 1045

\section{Introduction}

A wire cut machine is a $\mathrm{CNC}$ machine that works automotive through a computer control system. The wire-cut machine has the ability to produce high precision products with varying levels of surface finish was desired [1-2]. Surface finish, especially in some high-precision products, are parameters that need to be considered. Products produced with a certain level of surface roughness will determine the functionality of the product. The accuracy of the surface finish value of a product will determine whether the product works properly [3-4].
Wire cut machine is a nonconventional machine that is often used in various research objects [5-6]. Research concerning setting the wire cut cutting parameters on straight gears has been done before. Tosun et al [7] conducted a study on the effect of cutting parameters on surface roughness on wire cut with steel workpiece SAE 4140. This study concluded that pulse duration, open circuit voltage, and wire speed greatly affect the surface roughness cutting. Increasing the pressure of the dielectric fluid can be obtained by a finer cutting surface.

Fitriawan [8] conducted research on MRR (material removal rate) and surface roughness result of the cutting process of wire cut machine using the S45C stainless material. The surface finish with process parameter setting in this research was modeled by the power function equation which then transformed into equation linear. it was concluded that the roughness of cutting result and MRR in cut wire process is influenced by variable power setting, off time and tapper cutting angle.

Mahapatra and Patnaik [9] have also conducted research on the optimization of process parameters on the wire cut by using Taguchi method. The results of this study suggest that the current, frequency, and velocity of dielectric fluid flow and their interactions have a significant effect on cutting in increasing MRR, 
minimizing roughness of cutting results, and narrowing the cutting width.

This research also produces setting parameters of cutting wire cut process. This paper aims to optimize the cutting parameters for a minimum of surface finish and cutting time. The optimization of wire cut parameters was also performed by [10].

\section{Research Methodology}

\section{A. Materials and Cutting Tools}

Specification of the workpiece used in this experiment is AISI 1045 steel. While the type of wire used for the electrode wire cut is brass with a thickness of $0.25 \mathrm{~mm}$. The responses of surface finish can be measured using the surface tester of Mitutoyo SJ320. In this experiment, the wire cut machine of ONA AF25 was used to cut workpiece became gear.

\section{B. Cutting Parameters}

In this experiment, the cutting parameters were used to cutting the workpiece as shown in Table 1.

Table 1 . The cutting parameter for wire cut

\begin{tabular}{|l|c|}
\hline \multicolumn{1}{|c|}{ Parameters } & Units \\
\hline Current (Amp.) & 3,5, and 7 \\
\hline Wire Speed (mm/m) & 8,10, and 12 \\
\hline Wire diameter $(\mathrm{mm})$ & 0.25 \\
\hline Type of wire & Brass \\
\hline
\end{tabular}

\section{Results and Discussion}

The wire cut process has been performed on the AISI 1045 workpiece to form the gears. Furthermore, the next process is testing the surface finish, where the experimental results can be shown in Figs. 2 and 3.

In order to obtain a smooth machined surface and short of cutting time. Thus, it can be performed by the optimization of the cutting parameters by using software Design of Expert (DOE) Version 6.0. This software was also used in their experiments $[4,11,12]$. The result of ANOVA analysis was described in Table 2.

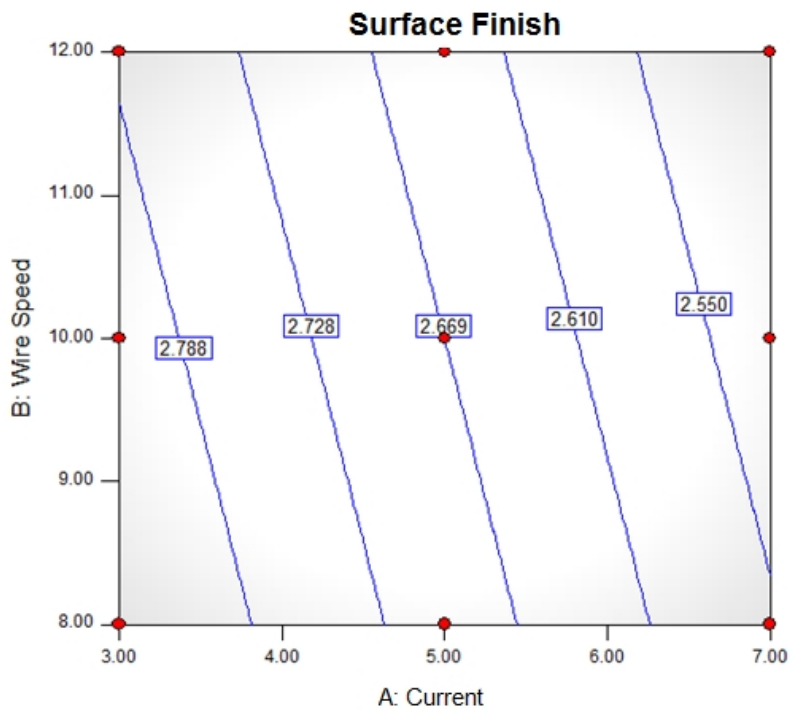

Figure 1. Surface finish model in plot 2D

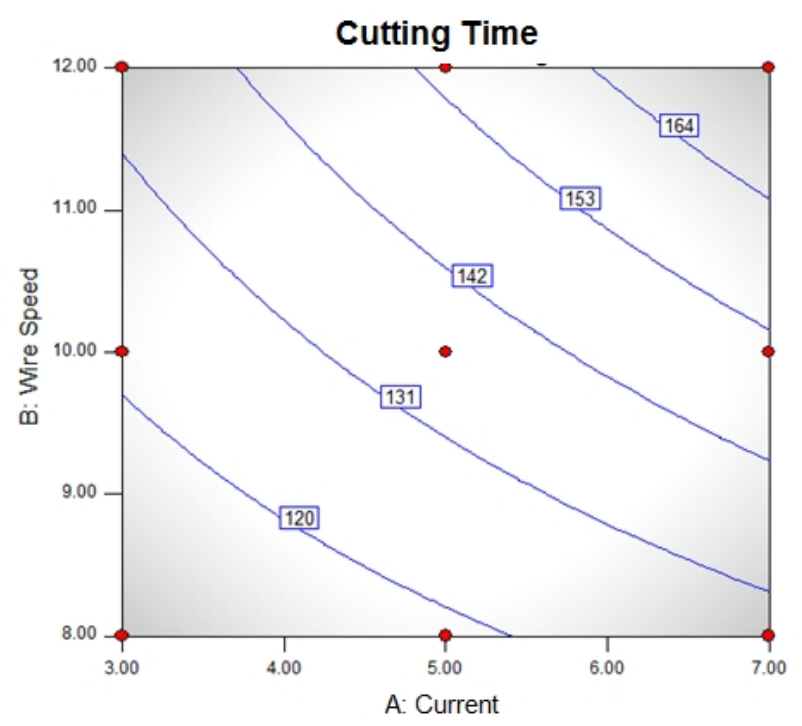

Figure 2. Cutting time model in Plot 2D

Table 2. ANOVA analysis for surface finish and cutting time

\begin{tabular}{|r|c|c|c|c|c|}
\hline \multicolumn{1}{|c|}{ Source } & $\begin{array}{c}\text { Sum of } \\
\text { squares }\end{array}$ & DOF & $\begin{array}{c}\text { Mean } \\
\text { square }\end{array}$ & F-value & Prob. $<\mathrm{F}$ \\
\hline $\begin{array}{l}\text { Surface } \\
\text { finish } \\
\text { Model }\end{array}$ & 0.13 & 2 & 0.067 & 13.04 & 0.0065 \\
$A$ & 0.13 & 1 & 0.13 & 24.84 & 0.0025 \\
$B$ & $6.34 \mathrm{E}-03$ & 1 & $6.34 \mathrm{E}-03$ & 1.24 & 0.3080 \\
\hline $\begin{array}{r}\text { Cutting } \\
\text { time }\end{array}$ & & & & & \\
Model & 3465.17 & 2 & 1155.06 & 71.45 & 0.0002 \\
$A$ & 1290.67 & 1 & 1290.67 & 79.84 & 0.0003 \\
$B$ & 2053.50 & 1 & 2053.50 & 127.02 & $<0.0001$ \\
$A B$ & 121.00 & & 121.00 & 7.48 & 0.0410 \\
\hline
\end{tabular}


The optimization model is used to know the combination of factor levels for each response simultaneously, where optimization can be performed numerically or graphically. This goal will be combined with the overall desire function to get the optimal solution including maximizing the function. Thus, the smooth surface finish value and fast cutting time value can be determined. The time parameter was also used by Makmur et al [13]. This parameter was measured the ejector system to eliminate the exhaust gas.

The final empirical model of surface finish and cutting time in the actual factor was as follows:

$$
\begin{aligned}
(\text { Ra })^{-1}= & 3.1953-0.0728 * \text { Current } \\
& -0.0163 * \text { Wire Speed } \\
(T c)^{-1}= & 75.9167-6.4167 * \text { Current }+2.3750 \\
& * \text { Wire Speed }+1.375^{*} C^{*} \text { Wire Speed }
\end{aligned}
$$

The optimal solution was suggested by the calculation results of DOE as shown in Figure 3. By simply changing the target, the solutions can be obtained for comparison purposes before the final selection of the factor setting.

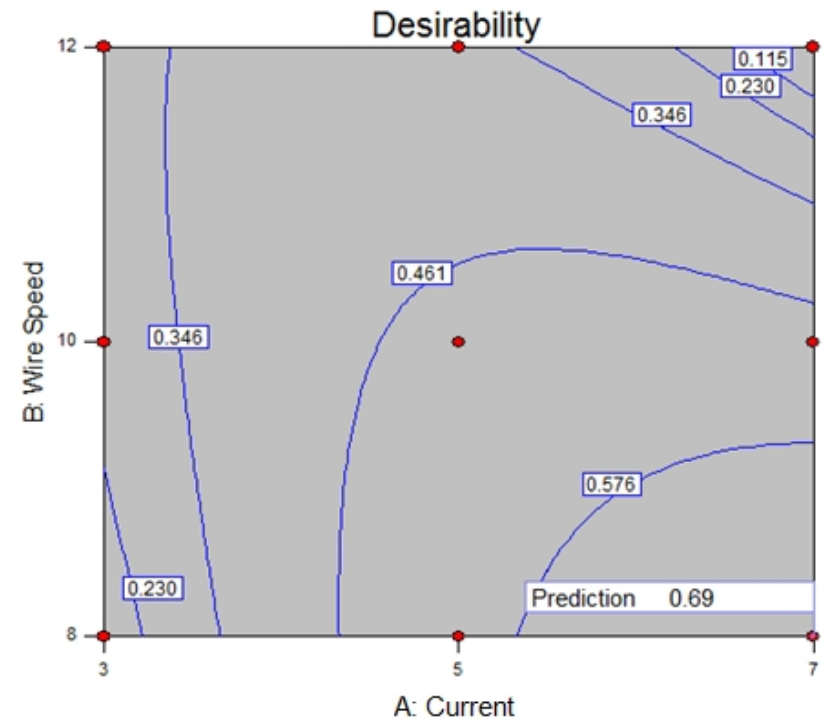

Figure 3. Optimization model in desirability plot

Graphical optimization involves creating a plot overlay generated by superimposing contours for different surface responses. The portion of the shaded plotted overlay is the boundary for all desired responses, as shown in Figure 4 which determines the value of the dependent variable allowed. In this particular case, it is desirable to determine the appropriate region for the process arrangement so that the surface roughness should not exceed $2,650 \mu \mathrm{m}$, and the cut-off result is $140 \mathrm{~min}(2 \mathrm{~h} 20 \mathrm{~min})$.

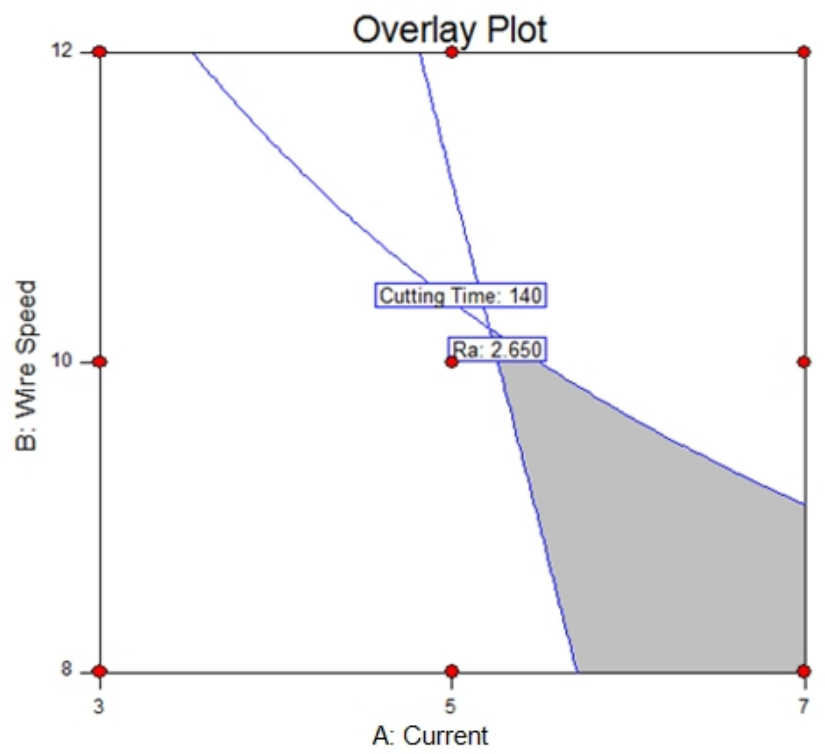

Figure 4. Optimization model in overlay plot

The cutting process on the wire-cut machine uses two variables: the current and the wire speed travel well. The result of surface roughness and cutting time is significantly influenced by strong variables of current and wire cut. This is in accordance with the facts proposed by Tosun et al [6] that wire speed is very influential on the roughness of the cutting surface. This phenomenon is also reported by a study conducted by Mahapatra and Patnaik [8] who examined the optimization of the parameters of wire cut EDM machining process by using the Taguchi method with the result that the magnitude of the current and the interaction gave a significant effect on cutting conditions in minimizing surface finish, and able to narrow the width of cutting.

In this experiment, it can be obtained for other responses such as power consumption [14-15], and energy consumption [16-17].

\section{Conclusion}

The conclusions that can be drawn from the experimental results are as follows:

1. The current variable gives a significant influence on the roughness of the straight gear surface. The 
greater the current was used, the surface finish of the straight gear is lower. The smaller the current is used, the higher the roughness of the straight gear surface.

2. Variable wire speed gives a significant effect on the roughness of the straight gear surface. The greater the value of wire speed that is used then the roughness of the straight gear surface is lower, otherwise the smaller the value of the speed used, the higher the surface roughness value.

\section{Acknowledgment}

We are acknowledging to the Politeknik Negeri Ujung Pandang for its assistance funded this research (Funding Number 018/PL10.13/PL/2018). We also thank the Mechanical Engineering Department for the support of laboratory equipment to complete our experiments.

\section{References}

[1] A.L. Livshits, Introduction, in: Electro-erosion Machining of Metals, Department of Scientific \& Industrial Research, Butterworth \& Co., London, 1960, p. x.

[2] Endri Agus Setyo. Teori Pemesinan EDM (Electrical Discharge Machine). 2011.

[3] Davim. J. Paulo. "A note on the determination of optimal cutting conditions for surface finish obtained in turning using design of experiments." Journal of materials processing technology 116.2-3, 2001, pp. 305-308.

[4] Nur, Rusdi, M. Y. Noordin, S. Izman, and Denni Kurniawan. "Machining parameters effect in dry turning of AISI $316 \mathrm{~L}$ stainless steel using coated carbide tools." Proceedings of the Institution of Mechanical Engineers, Part E: Journal of Process Mechanical Engineering 231, no. 4, 2017, pp. 676683.

[5] S. Kalpajian, S.R. Schmid, Material removal processes: abrasive, chemical, electrical and high-energy beam, in: Manufacturing Processes for Engineering Materials, Prentice Hall, New Jersey, 2003, pp. 541.

[6] Nur, Rusdi, and Muhammad Arsyad Suyuti. Pengantar Sistem Manufaktur. Deepublish, 2017.

[7] Tosun, N., C. Cogun, A. Inan. The Effect Of Cutting Parameters On Workpiece Surface Roughness In Wire EDM. Machining Science And Technology: An International Jurnal. 2003.

[8] Fitriawan, Hasmar Eko. Analisa Pengaruh Power Setting, Off Time, dan Sudut Taper Cutting Terhadap Kekasaran Hasil Proses Pemotongan Miring CNC EDM Wire Cut. Jurusan Teknik Mesin. Institute Teknologi Semarang. Semarang. 2003.

[9] Mahapatra, S.S, Patnaik, A. Optimization Of Wire Electrical Discharge Machining (WEDM) Process Parameters Using Taguchi Method. International Jurnal Of Advanced Manufacturing Technology, Vol. 34, 2007.
[10] Mulyadi, Agus Puji Suryanto. Optimalisasi Hasil Proses Wire Cut EDM dengan Metode Principal Component Analysis (PCA). Jurnal Rotor. Volume 9. Nomor 1. Teknik Mesin. Universitas Muhammadiyah Sidoarjo. Sidoarjo. 2016.

[11] Nur, Rusdi, Denni Kurniawan, M. Y. Noordin, and S. Izman. "Optimizing power consumption for sustainable dry turning of treated aluminum alloy." Procedia Manufacturing 2, 2015, pp. 558-562.

[12] Nur, R. Sustainable Machining By Optimizing The Power Demand Through Dry Turning Of 3161 Stainless Steel. Journal of Engineering and Applied Sciences ARPN Vol. 12 (6), 2017, pp. 1885-1889.

[13] Saini, M., Nur, R., Sattar, S., \& Ibrahim. I. Rancang Bangun Alat Eliminasi Gas Buang Menggunakan Mekanisme Ejektor. INTEK: Jurnal Penelitian, 2017, 4.2: 115-121.

[14] Nur, R., Suyuti, M.A. and Susanto, T.A., Optimizing cutting conditions on sustainable machining of aluminum alloy to minimize power consumption. In AIP Conference Proceedings (Vol. 1855, No. 1, p. 020002). 2017, June. AIP Publishing.

[15] Nur, Rusdi. Calculating the Power Demand in Turning of AISI 316L Stainless Steel Through the Cutting Forces Data. INTEK: Jurnal Penelitian 3, no. 1, 2016, pp. 43-49.

[16] Nur, R., B. Nasrullah, and M. A. Suyuti. "Sustainable manufacturing by calculating the energy demand during turning of AISI 1045 steel." In Journal of Physics: Conference Series, vol. 953, no. 1, p. 012028. 2018. IOP Publishing.

[17] Susanto, Tri Agus, and Rusdi Nur. "Experimental research to investigate the performance of bio coolant when turning of mild carbon steel." In IOP Conference Series: Materials Science and Engineering, vol. 191, no. 1, p. 012028. 2017. IOP Publishing. 